\title{
Mean-reverting behavior of current account in Asian countries
}

\author{
Evan Lau, Ahmad Zubaidi Baharumshah* \\ Department of Economics, Faculty of Economics and Management, Universiti Putra Malaysia (UPM), \\ 43400 UPM Serdang, Selangor Darul Ehsan, Malaysia
}

Received 26 April 2004; received in revised form 6 July 2004; accepted 12 January 2005

Available online 2 April 2005

\begin{abstract}
This paper adopted the series specific panel unit root test of Breuer et al. [Oxford Bulletin of Economics and Statistics 64 (2002, SURADF) 527-546] to test for the mean-reverting behavior of current account for the panel of twelve Asian countries. The results illustrate that the current accounts in these countries are a mixture of $I(0)$ and I(1) process and the commonly used panel root tests could lead to misleading inferences.
\end{abstract}

(C) 2005 Elsevier B.V. All rights reserved.

Keywords: Series specific panel unit root test; Mean-reverting; Current account

JEL classification: F32

\section{Introduction}

The mean reversion property of current account brings a number of implications to international macroeconomics. First, a stationary current account is consistent with sustainability of the external debts. In this case, there is no incentive for the government to make drastic policy changes and default on its international debts in the near future. Second, stationarity of the current account validates the modern intertemporal model (Wu, 2000). Theoretically, the model combines the assumptions of perfect capital mobility and consumption-smoothing behavior to postulate that the current account acts as a buffer to smoothing consumption in the event of shocks.

\footnotetext{
* Corresponding author. Tel.: +60 603 89467625x7744; fax: +60 60389467665.

E-mail address: zubaidi@putra.upm.edu.my (A. Zubaidi Baharumshah).
} 
The bulk of the empirical literature that utilized single-equation unit root tests rejects the meanreverting behavior of current account (Husted, 1992; Ghosh, 1995; Bergin and Sheffrin, 2000 and Baharumshah et al., 2003). The advancement in panel unit root tests pioneered by Levin and Lin (1993, LL) and the second-generation tests of Im et al. (1997, IPS), Sarno and Taylor (1998, ST), Harris and Tzavalis (1999, HT), Maddala and Wu (1999, MW), and Breitung (2000, UB) has increased the statistical power of unit root tests over the single-equation methods. Motivated by the statistical power of these tests, $\mathrm{Wu}$ (2000) found mean-reverting behavior of current account for a panel of 10 OECD countries.

A common feature of the panel tests mentioned above is that they maintained the null hypothesis of a unit root in all panel members. Therefore, their rejection indicates that at least one panel member is stationary, with no information about how many series or which ones are stationary. In addressing this issue, Breuer et al. (2002, SURADF) developed a panel unit root test that involves the estimation of the ADF regression in a SUR framework and then test for individual unit root within the panel member. This series specific panel unit root test procedure also handles heterogeneous serial correction across panel members.

The purpose of this paper is to re-examine the mean-reverting property of the current account in twelve Asian countries (Asian-12: Bangladesh, India, Indonesia, Japan, Korea, Malaysia, Nepal, Pakistan, Philippines, Singapore, Sri Lanka and Thailand) using the new panel unit root test of Breuer et al. (2002, SURADF). There are strong reasons for believing that there is considerable heterogeneity in the countries under investigation and thus, the typical panel unit root tests employed may lead to misleading inferences. To highlight this point, we also report the unit root test of Im et al. (1997, IPS), Harris and Tzavalis (1999, HT) and Breitung (2000, UB) to the same data set. ${ }^{1}$ Section 2 briefly describes the intertemporal optimization model of current account and the econometric strategy. Section 3 reports the empirical results while section 4 concludes.

\section{Current account model and econometric strategy}

\subsection{Current account model}

We use a simple variant of the intertemporal model based on Ghosh (1995) and Wu (2000) that considers a small open economy in which the world interest rate is fixed at $r$ with a quadratic utility consumption function. In such a model, the optimal current account can be represented as,

$$
C A_{t}=-\sum_{k=0}^{\infty} \frac{1}{(1+r)^{k}} E_{t} \Delta Q_{t+k}
$$

where $Q_{t}=Y_{t}-I_{t}-G_{\mathrm{t}}$ is the net output or national cash flow. Eq. (1) states that the current account (CA) is determined by future expectations of the changes in the net output. Notice that if $Q$ is $I(1)$, its first difference $\Delta Q$ will be stationary. This also means that $C A_{t}$ on the left-hand side of Eq. (1) is stationary.

\footnotetext{
${ }^{1}$ Sarno and Taylor (1998) demonstrated these types of panel unit root tests are biased towards stationarity if only one series is strongly stationary. Also, Breuer et al. (2001) presented the evidence that in the Levin and Lin test, the probability of rejecting the null of a unit root increased as the number of stationary series increased.
} 


\subsection{Series specific panel unit root test: SURADF}

The SURADF test is based on the system of ADF equations which can be represented as:

$$
\begin{aligned}
& \Delta y_{1, t}=\alpha_{1}+\beta_{1} y_{1, t-1}+\sum_{j=1} \varphi_{j} \Delta y_{1, t-j}+u_{1, t} \\
& \Delta y_{2, t}=\alpha_{2}+\beta_{2} y_{2, t-1}+\sum_{j=1} \varphi_{j} \Delta y_{2, t-j}+u_{2, t} \\
& \vdots \\
& \Delta y_{N, t}=\alpha_{N}+\beta_{N} y_{N, t-1}+\sum_{j=1} \varphi_{j} \Delta y_{N, t-j}+u_{N, t}
\end{aligned}
$$

where $\beta_{j}=\left(p_{j}-1\right)$ and $p_{j}$ is the autoregressive coefficient for series $j$. This system is estimated by the SUR procedure and the null and the alternative hypotheses are tested individually as

$$
\begin{array}{ll}
H_{0}^{1}: \beta_{1}=0 ; & H_{A}^{1}: \beta_{1}<0 \\
H_{0}^{2}: \beta_{2}=0 ; & H_{A}^{2}: \beta_{2}<0 \\
\vdots & \\
H_{0}^{N}: \beta_{N}=0 ; & H_{A}^{N}: \beta_{N}<0
\end{array}
$$

with the test statistics computed from SUR estimates of system (2) while the critical values are generated by Monte Carlo simulations. This procedure posed several advantages. First, by exploiting the information from the error covariances and allowing for autoregressive process, it produced efficient estimators over the single-equation methods. Second, the estimation also allows for heterogeneity in lag structure across the panel members. Third, the SURADF panel integration test allows us to identify how many and which members of the panel contain a unit root.

As this test has non-standard distributions, the critical values of the SURADF test must be obtained through simulations. In the Monte Carlo simulations, the intercepts, the coefficients on the lagged values for each series were set equal to zero. In what follows, the lagged differences and the covariances matrix were obtained from the SUR estimation on the actual current account data. The SURADF test statistic for each of the twelve series was computed as the $t$-statistic calculated individually for the coefficient on the lagged level. To obtain the critical values, the experiments were replicated 10,000 times and the critical values of $1 \%, 5 \%$ and $10 \%$ are tailored to each of the twelve panel members.

\section{Empirical evidence}

Annual data of current account and gross domestic product (in billions of US dollar) over the period 1970-2002 for Asian-12 were obtained from International Financial Statistics (IFS). Current account per output is constructed by dividing the current account by gross domestic product.

Table 1

Panel unit root tests results

\begin{tabular}{llllll}
\hline & \multicolumn{2}{l}{ Test statistics } & & & \\
\cline { 2 - 6 } & t-bar $(\mu)$ & t-bar $(\tau)$ & HT $(\mu)$ & HT $(\tau)$ & UB-t \\
\hline Asia-12 & $-2.031(0.021)$ & $-1.870(0.030)$ & $-4.203(0.000)$ & $-9.899(0.000)$ & $-5.108(0.000)$ \\
\hline
\end{tabular}

HT and UB indicate the Harris and Tzavalis (1999) and Breitung (2000) while t-bar represents the Im et al. (1997) panel unit root tests. All the three tests examine the null hypothesis of non-stationarity. The subscripts $\mu$ and $\tau$ indicate the models that allow for a drift term and both a drift and a deterministic trend, respectively. The Asia-12 includes the twelve individual current accounts grouped into one panel with sample $N=12, T=33$. The parenthesized values are the probability of rejection. 
Table 2

SURADF estimation and the critical values

\begin{tabular}{lllll}
\hline Country & Test statistics & & Critical values & \\
\cline { 2 - 5 } & SURADF & 0.01 & 0.05 & 0.10 \\
\hline Bangladesh & $-4.635(4)^{*}$ & -5.907 & -4.906 & -4.440 \\
India & $-2.171(2)$ & -5.336 & -4.330 & -3.830 \\
Indonesia & $-3.429(1)$ & -5.497 & -4.536 & -4.082 \\
Japan & $-3.954(1)$ & -5.665 & -4.736 & -4.218 \\
Korea & $-4.817(1)^{*}$ & -6.152 & -5.195 & -4.706 \\
Malaysia & $-2.376(3)$ & -6.049 & -5.028 & -4.505 \\
Nepal & $-3.053(4)$ & -5.989 & -5.018 & -4.507 \\
Pakistan & $-2.420(3)$ & -5.704 & -4.637 & -4.147 \\
Philippines & $-2.745(1)$ & -5.648 & -4.676 & -4.199 \\
Singapore & $-4.314(1)^{*}$ & -5.614 & -4.537 & -4.070 \\
Sri Lanka & $-3.539(2)$ & -5.989 & -4.922 & -4.454 \\
Thailand & $-2.166(1)$ & -5.896 & -4.885 & -4.403 \\
\hline
\end{tabular}

The SURADF column refers to the estimated Augmented Dickey-Fuller statistics obtained through the SUR estimation of the Asia-12 ADF regression. Each of the estimated equation excludes a time trend. The three right-hand side columns report the estimated critical values tailored by the simulation experiments based on 33 observations for each series and 10,000 replications, following the work by Breuer et al. (2002). (*) denote statistically significant at the 0.10 level.

The single-equation-based tests are applied to examine the null of a unit root in each series. Taken together, the results of the single-equation methods suggest that the current accounts are non-stationary for all cases, except for Bangladesh, Korea, Malaysia and Sri Lanka. To overcome this problem, we created a panel data set from the Asian-12 countries and summarized the results in Table 1. We find that the null hypotheses of non-stationary based on the three tests can easily be rejected at conventional significant levels for the full panel. According to Sarno and Taylor (1998) these panel unit root tests are meaningful only when the univariate tests fail to reject the unit root null. Dropping those countries that may be suspected of having sustainable current accounts did not change the results. $^{2}$

One way of resolving the ambiguity in the various unit root tests is to apply more powerful tests. As tabulated in Table 2, the null of non-stationarity is rejected in only 3 cases - Bangladesh, Korea and Singapore at the $10 \%$ significance level. This finding is in sharp contrast with the findings in Table 1. This is not surprising as the earlier panel unit root procedures are based on a joint test of the null hypothesis while the SURADF tests each member country individually using a system approach. In our view the weakness of the earlier panel based unit root test that built upon the joint testing principles fail to account for heterogeneity among the panel members. While these results are somewhat similar to the conclusion made from the univariate unit tests, the SURADF is much more efficient as it accounts for the contemporaneous cross-correlation information obtained from the SUR estimates. Indeed, Breuer et al. $(2001,2002)$ have shown that the SURADF has double to triple the power of the ADF test in rejecting a false null hypothesis.

\footnotetext{
2 The empirical results are not reported here but are made available upon request.
} 


\section{Conclusion}

The inference drawn from the IPS, HT and UB tests indicates all series in the panel are stationary while the SURADF suggests that 3 out of 12 series are stationary. The results reveal that the IPS, HT and UB tests can lead to misleading inferences in which they are biased towards the stationary even only one series in the panel is strongly stationary (Sarno and Taylor, 1998 and Breuer et al., 2001). Using the SURADF estimation however, we found that the rejection of the null of the joint non-stationarity of the series is being driven by a small number of countries within the panel. In sum, these results confirm the complex nature of the properties of the panel data. From a policy perspective, this finding suggests that current account imbalances in most of the Asian-12 countries, including those affected by the financial crisis (Indonesia, Korea, Malaysia, the Philippines and Thailand) are unpredictable.

\section{Acknowledgements}

The authors are grateful to Breuer, McNown and Wallace for providing the program code of SURADF in simulating critical values necessary for the testing of the hypothesis. This paper has benefited from the comments of Professor Emeritus Myles S. Wallace. The second author gratefully acknowledges financial support from the Malaysian government [IRPA grants No: 05-02-04-0532]. The usual disclaimer regarding errors and omissions applies.

\section{References}

Baharumshah, A.Z., Lau, E., Fountas, S., 2003. On the sustainability of current account deficits: evidence from four ASEAN countries. Journal of Asian Economics 14, 465-487.

Bergin, P.R., Sheffrin, S.M., 2000. Interest rates, exchange rate and present value models of the current account. Economic Journal 110, 535-558.

Breitung, J., 2000. The local power of some unit root tests for panel data. In: Baltagi, B., Fomby, T.B., Hill, R.C. (Eds.), Advances in Econometrics: Nonstationary Panels, Cointegration in Panels and Dynamics Panels, vol. 15, pp. $161-178$.

Breuer, J.B., McNown, R., Wallace, M.S., 2001. Misleading inferences from panel unit root tests with an illustration from purchasing power parity. Review of International Economics 9, 482-493.

Breuer, J.B., McNown, R., Wallace, M.S., 2002. Series-specific unit root tests with panel data. Oxford Bulletin of Economics and Statistics 64, 527-546.

Ghosh, A., 1995. International capital mobility amongst the major industrialized countries: too much or too little? Economic Journal 105, 107-128.

Harris, R.D.F., Tzavalis, E., 1999. Inferences for unit roots in dynamic panels where the time dimension is fixed. Journal of Econometrics 91, 201-226.

Husted, S., 1992. The emerging U.S. current account deficit in the 1980s: a cointegration analysis. The Review of Economic and Statistics 74, 159-166.

Im, K.S., Pesaran, M.H., Shin, Y., 1997. Testing for unit roots in heterogeneous panels. Working Paper. University of Cambridge.

Levin, A., Lin, C. F., 1993. Unit Root Tests in Panel Data: New Results. University of California at San Diego (UCSD) Discussion Paper No. 56.

Maddala, G.S., Wu, S., 1999. A comparative study of unit root tests with panel data and a new simple test. Oxford Bulletin of Economics and Statistics 61, 631-652.

Sarno, L., Taylor, M.P., 1998. Real exchange rates under the recent float: unequivocal evidence of mean reversion. Economics Letters $60,131-137$.

Wu, J.L., 2000. Mean reversion of the current account: evidence from the panel data unit-root test. Economics Letters 66, 215-222. 